Meta

Journal des traducteurs

Translators' Journal

\title{
Employing psycholinguistics to examine effects of conference interpreting experience and training on lexical production
}

\section{Agnieszka Chmiel}

Volume 60, numéro 2, août 2015

$60^{\mathrm{e}}$ anniversaire. Les horizons de la traduction : retour vers le futur $60^{\text {th }}$ Anniversary. Translation's Horizons: Back to the Future

60mo aniversario. Los horizontes de la traducción: regreso al futuro

URI : https://id.erudit.org/iderudit/1032870ar

DOI : https://doi.org/10.7202/1032870ar

Aller au sommaire du numéro

Éditeur(s)

Les Presses de l’Université de Montréal

ISSN

0026-0452 (imprimé)

1492-1421 (numérique)

Découvrir la revue

Citer ce document

Chmiel, A. (2015). Employing psycholinguistics to examine effects of conference interpreting experience and training on lexical production. Meta, 60(2),

319-319. https://doi.org/10.7202/1032870ar 


\title{
Employing psycholinguistics to examine effects of conference interpreting experience and training on lexical production
}

\author{
Agnieszka Chmiel \\ Adam Mickiewicz University, Poznań, Poland \\ Agnieszka.Chmiel@amu.edu.pl
}

It is assumed that the specific use of languages by conference interpreters influences the organisation of the bilingual mental lexicon and lexical processing (Christoffels, De Groot and Kroll 2006). Longitudinal studies using psycholinguistic research methodology create an opportunity to examine whether interlingual links between translation equivalents in the mental lexicon strengthen over time and lead to better interpreting performance. While it is difficult to pursue such research with professional interpreters, it is more feasible to examine interpreting trainees at the beginning and at the end of their training and to compare their performance to experienced professionals. In order to shed more light on the influence of conference interpreting experience and training on interlingual lexical links in the mental lexicon and lexical access, a task involving interpreting of single words in various context constraints has been devised. Twenty-four professional interpreters and twenty-two interpreting trainees (tested at the beginning and at the end of their 2-year training programme) were compared while interpreting sentence-final words in three context constraints: high context constraint, low context constraint and no context constraint. All participants had Polish as their A language and English as their $B$ language and worked/were trained in both interpreting directions ( $\mathrm{A}$ into $\mathrm{B}$ and $\mathrm{B}$ into $\mathrm{A}$ ). No asymmetries were found between interpreting from $A$ into $B$ and vice versa, but group effects revealed stronger interlingual lexical links in the professionals' mental lexicons and the effect of experience on the production of translation equivalents. Shorter latencies in the high context constraint condition showed that sentence context affects word processing (in line with van Hell 2005), which inspires further inquiry into how lexical context might facilitate interpreting.

Agnieszka Chmiel is Assistant Professor in the Department of Translation Studies at the Faculty of English, Adam Mickiewicz University in Poznań, Poland. Her research interests include conference interpreting, audio description, audiovisual translation, psycholinguistics, memory and visual imagery in interpreting. She has recently studied the process of sight translation by using eye tracking (Chmiel and Mazur 2013) and translation of cognates by interpreting trainees and non-interpreting trilinguals (Lijewska and Chmiel 2015). Her recent book Audiodeskrypcja (2014), co-authored with Iwona Mazur, is the first comprehensive study of audio description as a type of intersemiotic audiovisual translation available in Polish. 